\title{
RELOCATION, STANDARDIZATION AND VERTICAL SPECIALIZATION: CORE-PERIPHERY RELATIONS IN THE EUROPEAN AUTOMOTIVE VALUE CHAIN ${ }^{1}$
}

\author{
TAMÁS GERÖCS ${ }^{1}$ - ANDRÁS PINKASZ ${ }^{2}$ \\ ${ }^{I}$ Institute of World Economics, Hungarian Academy of Sciences, Budapest, Hungary \\ Email: gerocs.tamas@krtk.mta.hu \\ ${ }^{2}$ Hungarian Central Statistical Office, Budapest, Hungary \\ Email: andras.pinkasz@ksh.hu
}

\begin{abstract}
The global automotive industry has been exposed to an overproduction crisis for several decades. Under the pressure of restructuring, automotive companies renew both the geographical scope and the technological standardization of their production processes. We analyze the effects this restructuring had on the development of European economies in order to understand whether vertical specializations in the automotive value chain can lead to Central and Eastern European countries' catching up to advanced economies, or whether such specializations reproduce new forms of coreperiphery relations. In order to answer this question, we introduce a new methodological approach to understand vertical specialization in the global value chain from a semi-peripheral perspective. We combine the theory of global value chains with Vernon's product life-cycle theory. In the research we focus on the standardization of the production of electric engines behind the geographical relocation of production between core and periphery.
\end{abstract}

Keywords: core-periphery, dependent development, global automotive value chains, product life cycle, relocation, vertical specialization

JEL-codes: F62, F50, F15

1 The research was co-financed by the research project "From developmental states to new protectionism: changing repertoire of state interventions to promote development in an unfolding new world order" (OTKA FK_124573), supported by the Hungarian National Research, Development and Innovation Office (NKFIH). We sincerely thank those who have commented on earlier versions of this paper, including members of the Working Group for Public Sociology "Helyzet", researchers of the Institute of World Economics, Márton Czirfusz, Pinar E. Dönmez, Ágnes Gagyi, Péter Gedeon, Csaba Jelinek, Andrea Komlosy, Martin Krzywdzinski, Tibor Meszmann, Mary Taylor and two anonymous reviewers. 


\section{INTRODUCTION}

In recent years, Central and Eastern European (CEE) countries have experienced major industrial restructuring, the process of which has been intensified by the relocation of production from advanced economies. CEE has provided production sites with low wages, flexible labor regulations, and tax incentives for companies in search of new opportunities to adapt to the dire global market conditions. The significance of the automotive industry is demonstrated by their share in these countries' industrial output.

Since the early 2000s, fierce market competition has forced automotive companies to expand the geographical scope of their production networks, and also to keep production costs under control. This has triggered vertical specialization in the European automotive value chains. At the top of the value chain hierarchy, companies have remained geographically concentrated in Western Europe, whereas those who specialized in more standardized activities have transferred production to Eastern Europe (see the increasing production of cars in the region shown in Figure 1).

Our hypothesis is that the emerging hierarchy of vertical specialization in value chains corresponds to the core-periphery relationship. In this paper we will analyze the economic mechanisms that reproduce core-peripheral hierarchies in the value chain context. Furthermore, we will examine their broader social con-

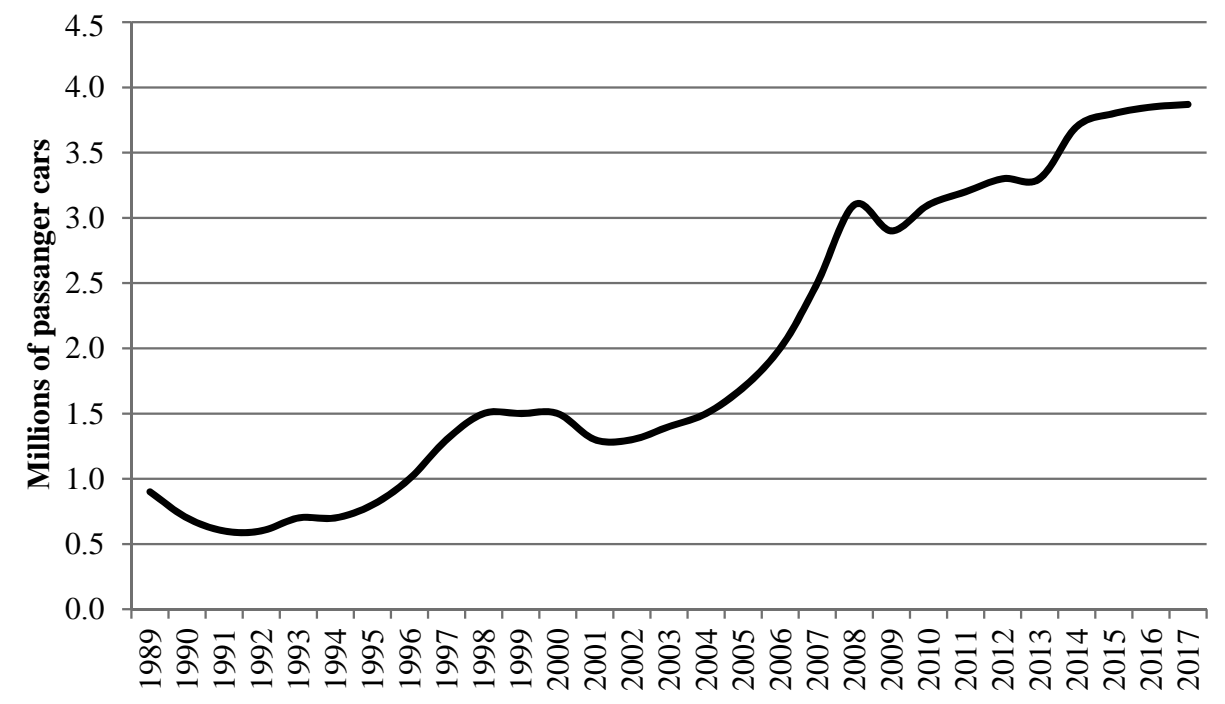

Figure 1. Car production in Central and Eastern Europe, 1989-2017

Source: authors, based on the OICA database. 
sequences on CEE countries which are historically on the European periphery. We argue that standardization of production and technologies in production, especially when standardization decelerates, are the major forces that cause relocation. As a consequence, despite the advancements in technological capabilities in peripheral production, the value added capacity does not automatically improve; in fact, diminishing capacity for producing added value can be the result of specialization entailed by standardized technologies.

In order to analyze core-periphery relationships of vertical specialization in the automotive industry, we have combined the framework(s) of global value chains and production networks (GVC/GPN) with Vernon's product life-cycle theory. On the one hand, the GVC/GPN framework stresses the geographical aspects of value-chain governance. On the other hand, product life-cycle theory explains how different forms of rent are made possible by the standardization of production. Although relocation in the automotive industry had already started at the beginning of the 1990s, and has been triggered by different economic forces since then, in this paper we will focus on one major global force which has become more pronounced since the world economic crisis in 2008. Technological transformation has become one of the main driving forces for relocating standardized technology for the production of combustion engines. We argue that the crisis was a major turning point in the life-cycle of combustion engines as they entered into the maturity phase. The declining phase in the life cycle of combustion engines intersects with the acceleration of the standardization of electric engines, which therefore becomes more substitutive to the combustion engine. In order to analyze the intersection between their life-cycles and the effects they have on the geographical relocation of production, we apply Vernon's theory to two substitutive products. ${ }^{2}$

Most studies analyzing Central and Eastern Europe's economic dependence concentrate exclusively on interstate economic relations. And while world-system scholars have traced the core-periphery relationship to different nodes of the world economy, including regional and inter-firm levels, the intrinsic linkages between these various levels and the mechanisms through which the multiscale system operates continue to be underexplored. The methodological aim of our paper is to establish a clear set of links between the global and local levels of the international division of labor in order to examine the question of dependency from the broadest possible perspective. By exploring the links between these different

2 Technological innovation is driven not only by electric cars' engines, but also by their batteries. In the following paper, we regard the two components as technologically inseparable elements of a complex powertrain; economically, however, we will treat them separately, given that batteries are often supplied by different firms, in some cases competitors of those firms that develop electric engines. 
levels of the system, we intend to describe the ways in which macro-structural dependencies are produced and reproduced by interfirm relationships within the production process.

The theory of dependency is nothing new; it dates back to the interwar and immediate post-war developmental concepts of scholars in Latin American and certain Western and Eastern European countries (Cardoso 1972; Gereffi - Evans 1981; Weissenbacher 2018). More recently, scholars in the tradition of Critical Political Economy have introduced the concept of the dependent market economy, which combines the notion of dependency with analyses of the role of the state in different varieties of capitalism (Bohle - Greskovits 2012; Vliegenthart 2010; Nölke 2016; Becker 2016). Proponents of the 'varieties of capitalism' approach have thoroughly studied the expanding role of foreign manufacturers in Central and Eastern Europe (Šćepanović 2013; Bernaciak 2011), while other institutionalists - for instance, analysts of regulation such as those of GERPISAhave focused more on 'work models' and institutional compromises in the automotive industry (Boyer - Freyssenet 2002; Krzywdzinski 2008).

Unlike institutionalists' models of the 'varieties of capitalism,' structural Marxists' analyses have long emphasized the uneven and combined development exhibited by the 'new international division of labor' (Fröbel et al. 1981; Wallerstein 1976; Chase-Dunn 1998). Marxist political economists' studies have also emphasized the illusory benefits of industrial development on the Southern periphery, arguing that technological transformation plays a pivotal role in the reproduction of core-periphery relationships (Arrighi 1990; Brenner 2006; Roberts 2016).

Our analysis is based on a notion of uneven and combined development which resembles these structuralists' concepts. We want to understand how uneven global distribution of state of the art technologies contribute to the reproduction of core-periphery relationships. Vernon's product life-cycle theory (1966) on standardization demonstrates how the introduction of innovative technologies devalues existing production processes by diminishing their capacity for creating value. Such devaluation affects not only production processes, but also forms of labor organization and the rates of return on older technologies still in operation.

According to Vernon's theory, the constant pressure of devaluation means that transfers of technology do not automatically result in upgraded production processes. Even switching a production line over to a new model can accelerate the life cycle of the given product and push it into decline - a process which tends to be ignored by proponents of the theory of upgrading (Gereffi - Korzeniewicz 1994; Henderson et al. 2002; Gereffi et al. 2005; Bair 2005; Gereffi 2014; Baldwin et al. 2014). The latter concentrate on one particular segment of the production process or on one particular model, the transfer of which they understand as a dynamic improvement in the technological endowments of the given production facility. 
The advantage of Vernon's theory is that it encompasses both technological shifts and the reorganization of entire production processes, including spatial relocation and the reproduction of geographical hierarchies within the division of labor. One disadvantage of this theory is that it was initially applied only to US-based firms, and thus generally neglected questions of ownership. We have therefore modified Vernon's product life-cycle theory by incorporating it into a framework including GVC and GPN theories. In our framework, the links between Vernon's theory and the GVC/GPN approaches are the different forms of economic rent which various players extract over the course of a product's life cycle.

The important contribution of GVC/GPN theorists to the analysis of global dependencies is their focus on the ownership structure of the supply chain; their approaches are also useful for analyzing modes of organizing labor and the relationships between production and regulation (Sturgeon - Van Biesebroeck 2011; Smith 2015). In applying GVC and GPN theories, we also incorporate Vernon's notions about the role of technology in the production process. As we noted above, the weakness of the theory of upgrading espoused by GVC/GPN scholars is that it neglects the uneven and contradictory effects new technologies have on the production process as a whole. We have used this synthetic approach-including elements of the GVC/GPN frameworks and Vernon's product life-cycle theoryto examine the automotive industry in CEE because that is where international car assemblers have been expanding their production capacity.

The rest of this paper consists of three further sections. In section 2 following this introduction, we explain how technological transformation makes vertical specialization possible through relocation. To demonstrate this we analyze the relationship between the declining phase of the combustion engine's life cycle and the more advanced standardization in the development of electric engines. In section 3, we highlight the effects of the relocation of European, mostly German, automotive companies on (1) labor productivity and capital intensity, (2) modes of labor organization and value capture, in short: on the results of vertical specialization. And finally, in our concluding remarks, we highlight that core-periphery relationships are reproduced by new forms of vertical specialization in the automotive value chain.

\section{THE RELATIONSHIP BETWEEN TECHNOLOGICAL TRANSFORMATION AND GEOGRAPHICAL RELOCATION}

In order to understand the effects that vertical specialization in the European automotive value chains have had on Central and Eastern European countries, we need to look at the forces behind industrial relocation. When profit prospects for 
combustion engines became bleak in the 1990s, standardized mass production was transferred to new geographical locations. Since the end of the 2000s another major impetus has been the standardization of the production of electric engines, which has helped push the combustion engine further into the mature phase of its life cycle. In this paper we focus on post-2008 developments, since when CEE countries' vertical specialization in the European automotive value chains has targeted the production of the latter engine type, and therefore the position these economies occupy is increasingly limited to the lower end of the value chain.

As an analytical starting point, we combine Vernon's product life-cycle theory (Vernon 1966) with the GVC/GPN framework. This helps us connect the different stages of product development to the changing profit conditions created by the process of standardization. In each stage of product development, companies seek new strategies to extract various forms of rent from the valuecreation process (Henderson et al. 2002: 448-449; Kaplinsky 1998): monopoly rent, technological rent and exploitation rent. The source of the monopoly rent comes from the fact that the product in concern has no substitutive alternative due to its pioneering introduction in the market. The source of the technology rent stems from technological standardization that helps to bring down production costs. Although all forms of rent include some sorts of exploitation in a capitalist system, it is the exploitative rent which makes the extraction and exploitation of material resources intensified when technological innovation is not enough or over-exhausted to solve the problem of competitive pressure or the simultaneous overproduction crises. Exploitative rent is the resource-seeking solution to the exhaustion of the other forms of rent by either intensifying the labor process or by relocating production closer to material resources, including cheap labor.

In the first stage of Vernon's model, when a new product is introduced commercially, the market price has less to do with initial production costs than with the monopoly position that the pioneering producer has achieved in its market niche. During the early phase of product development, companies are better able to afford high expenditures on innovations because their costs can be covered by this monopoly rent.

In the second stage, when new competitors enter the market, the standardization of production processes transforms the type of rent to be extracted. Monopoly rents evaporate as escalating competition puts downward pressure on both prices and profits. In this stage, production costs tend to determine prices. In order to sustain their rates of profit, companies must find technologically innovative ways to standardize their production processes. Their rents are almost directly associated with the degree of standardization they achieve. Any advances in its processes of standardization will allow a company to reap extra benefits without changing 
prices - at least until their innovative technologies are emulated by competitors. This source of profit, technological rent, cannot be sustained over the long run if competition intensifies.

During the standardized stage of production, profits come under increasing pressure and price competition will ultimately regulate the market. When standardization cannot be intensified at the same speed with which competition is accelerating, the material costs of production, including raw materials and labor, become the most important arenas for price competition. In this sort of competitive environment, companies are encouraged to seek new strategies, such as geographical relocations of the standardized segments of their production processes. This leads to the final stage of the product life cycle, in which a third type of rent arises from strategies like geographical relocation. We call this exploitative rent.

Nevertheless, product development and the geographical division of production are not necessarily directly related to core-periphery relationships. Before they are integrated into standardized production systems, important technological innovations are fostered in various locations irrespective of the host country's position in the international division of labor. In fact, domestic start-ups and garage firms all over the world conduct some of the most important technological experiments in the early stages of product development. A new division of labor emerges as production is adapted to standardized production systems. In addition, the geographical extension of production accelerates as larger multinationals acquire such technologies and integrate them into their established production networks.

The structural hierarchy of production, therefore, crystallizes only when a product's development reaches the final stage. It is only when standardized production is relocated to a new geographical region that companies are able to generate exploitative rents. The more standardized the production process of a given product becomes, the more likely its production is to be relocated to the periphery. Thus the hierarchical, core-periphery structure of a production process crystallizes not at the beginning of a product's life cycle, but as the culmination of its standardization.

In the following, we expand Vernon's single product model to cover two substitute products. Even in the case of a single product in the standardized stage, its price cannot drop at a continuous rate if improvements in the scale efficiency of its production slow down. Thus, despite continuous downward pressure on prices, the speed at which they fall decreases over time. Thus for two substitute products, each of which may be in a different stage of its life cycle, the price process described above results in a price convergence which accelerates over the long run. Therefore, at a later stage of development, the competition between the two substitute products will intensify. 
For incumbent companies facing growing price competition in a market for substitute products, this raises two questions. First, to which product will the company allocate more of its limited investment and development funds? And second, how will it reorganize the production process for the product with bleaker prospects for technological rents in the more standardized phase of its life cycle? The mechanism through which the two substitute products' life cycles interact in a price competition is the allocation of investment funds, which follows the shifts from one form of rent to another. More funds tend to be allocated to the less-mature product with higher expected returns on technological investments, leaving less capital to be put into the standardized product with the declining rate of return. In both cases, we see an acceleration of such interaction processes. The more funds are allocated to a product in the process of standardization, the faster its standardization proceeds. At the same time, as less capital remains to be invested in the standardized product, the faster such a product tends to decline into the final stage of its life cycle. For the less-mature product, this process will bring an acceleration of its standardization, while the product already in the standardized stage will move rapidly toward a market exit. In the latter case, companies can still slow down this exit process, and thus minimize their losses on previous investments by pushing down material costs and seeking exploitative rents through strategies like geographical relocation, as described above.

In case of the geographical relocation of the automotive industry, we find an underlying interaction between the life cycles of the combustion engine, which is in its standardized phase, and the electric engine, which is now in the process of rapid standardization. We assume that the combustion engine originally had a stronger and more direct influence on companies' investment strategies than did the development of the electric engine. The direction of influence, however, has changed over time. As the standardization of the less mature electric engine proceeds, while the more standardized combustion engine moves toward 'overmaturity,' with very little room for further development, investment has begun to shift toward the former. The electric engine, as it enters its more standardized phase, tends to attract more and more of a company's limited investment funds, effectively drawing them away from the combustion engine. We can see the evolution of the cost and energy density of electric batteries in Figure 2; the average cost of an electric battery tends to fall as its efficiency gradually increases.

Even though electric cars have only recently become available commercially, the early stages of their product life cycle stretch back to the 1920s, just after the revolutionary innovation of the moving assembly line, which Henry Ford first installed in 1913. The initial stage of the electric car's life cycle lingered on for almost a century because the prospects for its development were determined by the life cycle of the combustion engine or Otto motor. Despite the existence of 


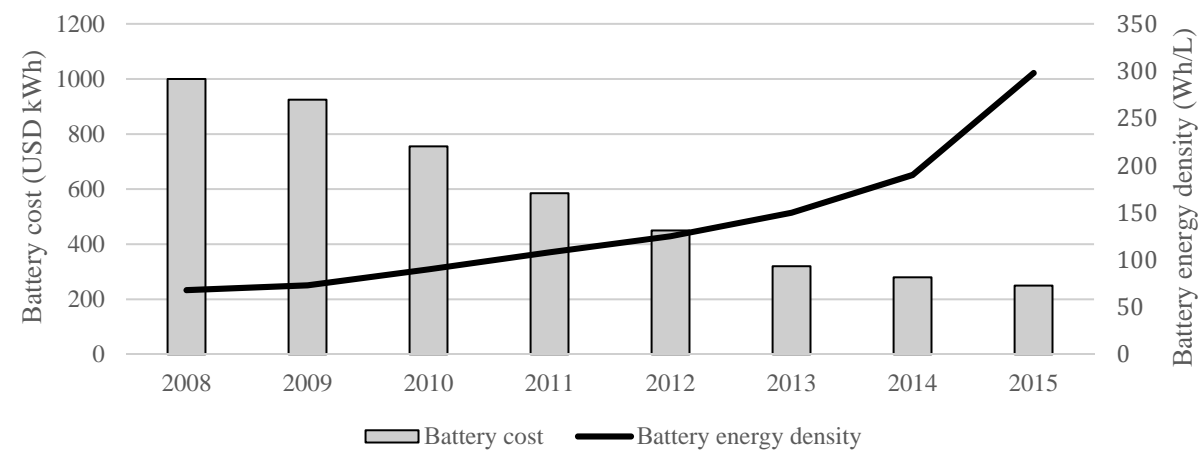

Figure 2. Electric battery cost and battery energy density

Source: Shanan (2016).

several prototypes, none of these electric models reached the stage of standardized production, ${ }^{3}$ largely because of Ford's revolutionary innovations in the production of combustion engines a decade earlier. The rapid standardization of the Ford model attracted a great deal of investment, kick-starting a boom in the life cycle of the Otto motor. It took less than a decade for this model to conquer the US and world markets, and even today, the widespread standardization of electric models is still largely dependent on the evolution of the Otto motor's life cycle. In other words, the standardization of electric-car production will speed up when the life cycle of the Otto motor approaches its end. Although this process has begun to accelerate since the oil-price shocks of the 1970s (at which point the Otto motor reached the stage of maturity), there is still a long road ahead (Figure 3).

The world economic crisis of 2009 seems to have accelerated the movement of the combustion engine into the declining phase of its life cycle. One consequence has been that companies in the European automotive value chain have accelerated the relocation of their production to CEE in hopes of generating exploitative rents. Returns on technological investments - those aimed at super-standardization and efficiency gains, especially in the downsizing of diesel engines-have dropped to historically low levels. As a result, returns on investments aimed at improving electric cars' efficiency tend to threaten companies that lag behind 


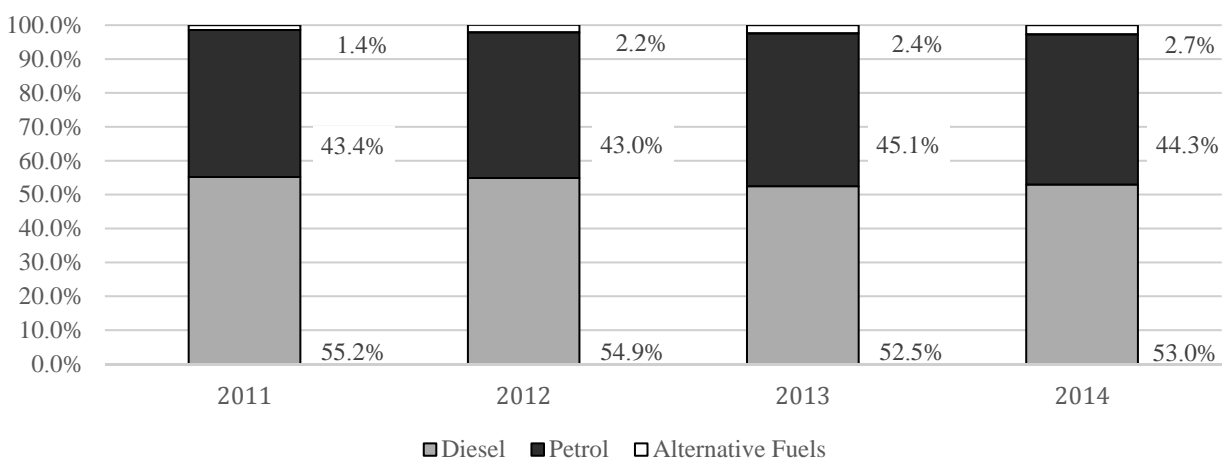

Figure 3. Market share of fuel types for newly registered cars in the EU, 2011-2014

Source: authors, based on ACEA and BMI database.

in this technological transformation. ${ }^{4}$ We assume that the standardization of the mass production of electric engines has been underway since the aftermath of the 2009 crisis. ${ }^{5}$ However, because of the influence investments in electric and combustion engines have on each other, OEMs' attempts to continue generating returns on their investments in the sinking combustion segment create strong tailwinds for relocation. Some of these investments might still turn a profit if production is relocated to regions where value can be created by generating exploitative rents. Peripheral economies, including CEE are among the best possible choices for expanding the production of standardized models that are moving toward the ends of their life cycles because of the low cost of material inputs there, most notably cheap labor.

4 A global survey conducted by KPMG found that a majority of responding managers of OEMs in the US, EU, and Japan had shifted their investment priorities away from the efficiency gains of downsizing combustion engines and started allocating more funds to innovation in electric and hybrid fuel systems (KPMG 2015: 17).

5 The emergence of Tesla's Model 3 and the growing number of technological innovations introduced by traditional OEMs - such as Renault-Nissan's Leaf, BMW's i3, and GM's Chevrolet Bolt — provide evidence for an increasingly intense interaction between the life cycles of the two substitute engines. Major German OEMs have lagged behind in this transformation, possibly as a result of the more traditional governance structure of their value chains. Very recently, however, both Daimler and VW have launched massive, multi-billion-dollar initiatives in hopes of catching up in this fiercely competitive race. See, for instance, Daimler's 'Ecolux project' and VW's 'Together-Strategy 2025.' 


\section{ECONOMIC AND SOCIAL EFFECTS OF VERTICAL SPECIALIZATION IN THE EUROPEAN AUTOMOTIVE VALUE CHAIN}

As a result of vertical specialization in the automotive industry, both the share of CEE in global automotive production and the industry's share in these economies' manufacturing output (Table 1) have been climbing steadily since the middle of the 1990s. As we have demonstrated in section one, since about the end of the 2000s, this relocation has been driven largely by the accelerating standardization of electric-engine production and the consequent shift of the combustion engine - the production of which CEE has specialized in - into the declining stage of its life cycle. In this second section, we analyze how this automotive-industry relocation has affected the social and economic relations both in and between Western Europe, especially Germany and Central and Eastern Europe in the following areas: (1) labor productivity and capital intensity and (2) modes of labor organization and capturing value.

Table 1. Share of CEE in global automotive manufacturing

\begin{tabular}{|c|c|c|c|c|c|c|}
\hline & \multirow{2}{*}{\multicolumn{2}{|c|}{$\begin{array}{c}\begin{array}{c}\text { Number of vehicles } \\
\text { produced }\end{array} \\
1000 \text { units } \\
\end{array}$}} & \multicolumn{4}{|c|}{$\begin{array}{c}\begin{array}{c}\text { Share of countries in CEE and global automobile } \\
\text { manufacturing }\end{array} \\
\end{array}$} \\
\hline & & & \multicolumn{2}{|c|}{$\begin{array}{l}\mathrm{CEE}= \\
100 \%\end{array}$} & \multirow{2}{*}{$\begin{array}{c}\text { Global }= \\
100 \% \\
2000\end{array}$} & \multirow{2}{*}{$\begin{array}{c}\text { Global }= \\
100 \% \\
2017\end{array}$} \\
\hline & 2000 & 2017 & 2000 & 2017 & & \\
\hline Germany & 5,525 & 5,646 & $81.2 \%$ & $62.2 \%$ & $9.5 \%$ & $7.7 \%$ \\
\hline Czech Republic & 456 & 1,414 & $6.7 \%$ & $15.6 \%$ & $0.8 \%$ & $1.9 \%$ \\
\hline Poland & 505 & 515 & $7.4 \%$ & $5.7 \%$ & $0.9 \%$ & $0.7 \%$ \\
\hline Slovakia & 182 & 1,002 & $2.7 \%$ & $11.0 \%$ & $0.3 \%$ & $1.4 \%$ \\
\hline Hungary & 137 & 502 & $2.0 \%$ & $5.5 \%$ & $0.2 \%$ & $0.7 \%$ \\
\hline Aggregate & 6,805 & 9,079 & $100.0 \%$ & $100.0 \%$ & $11.7 \%$ & $12.4 \%$ \\
\hline Global Aggregate & 58,374 & 73,457 & & & $100.0 \%$ & $0.0 \%$ \\
\hline
\end{tabular}

Source: OICA database.

\subsection{Labor productivity and capital intensity}

To understand the hierarchical nature of the automotive industry, we need to analyze labor productivity and capital intensity in various phases of the production process. For this purpose, we use world-systems scholars' definition of the coreperiphery relationship: 'a continuous variable between constellations of economic activities which vary in terms of their average relative levels of capital intensity versus labor intensity' (Chase-Dunn 1998: 207). Capital intensity means a high level of investment in non-standardized, i.e. relatively monopolistic spheres of 
production that usually erect barriers to prevent competitors from entering the market. Thus, high capital intensity also means monopoly rents and a relatively high proportion of skilled workers. On the other end of the theoretical spectrum, we find more standardized activities with declining productivity rates and a relatively larger share of unskilled labor, which we regard as the labor-intensive segment of the market. It is important to note that the terms of this analytical dichotomy cannot be used to describe any particular activity over a long period of time as the profile of any of such activity is prone to change due to the process of standardization. What we regard as a capital-intensive activity with high labor productivity on the day a product is introduced will soon be transformed into a more standardized, labor-intensive activity.

We turn our focus to the European automotive value chains to identify aspects of a core-periphery relationship among the various activities in the production process. In the West, center of production, specialization occurs in product development and other capital-intensive activities, e.g., producing special machine tools in the service of mass production (Krzywdzinski 2014: 6). The production of such machinery requires a relatively large proportion of highly qualified workers for whom there is competition in the labor market. Technological innovation associated with product development is usually also retained in the headquarters under the strict control of OEMs and tier-1 firms' global operations. The R\&D activities relocated to the Central and Eastern European countries, on the other hand, assure that local suppliers will be able to keep up with the uninterrupted flow of technological adaptations. ${ }^{6}$ Therefore, R\&D does not necessarily correspond with real product development. ${ }^{7}$ Differing modes of specialization in the automotive industry can make spectacular differences in the productivity of a local economy (Figure 4). Moreover, available information on export portfolios also suggests that none of the Central and Eastern European countries have specialized in the production of goods and activities associated with product development or trade linkages to the 'upstream' segment of the value chain. Instead, as is also stressed by the IMF (2013: 3), a large proportion of foreign value-added

6 These adjustments are necessitated by periodical model upgrades in already established lines of production. One recent example is the transfer of Audi's Q3 model to the Hungarian VWplant in Györ between 2016 and 2018. Four models were previously assembled there: the TT Coupe, TT Roadster, A3 Limousine, and Cabrio. These models became outdated as they reached the midpoint of a medium-sized car's average life cycle, which industry experts estimate at 6 years. After a model reaches middle age, its sales tend to drop, a process catalyzed for some of these vehicles by the 2015 diesel scandal (Portfolio 2016).

7 In our analyses the relocation of R\&D is not a reliable measure of economic development. As some individual cases suggest companies can account for R\&D activities only because of special tax credits or other financial incentives. 


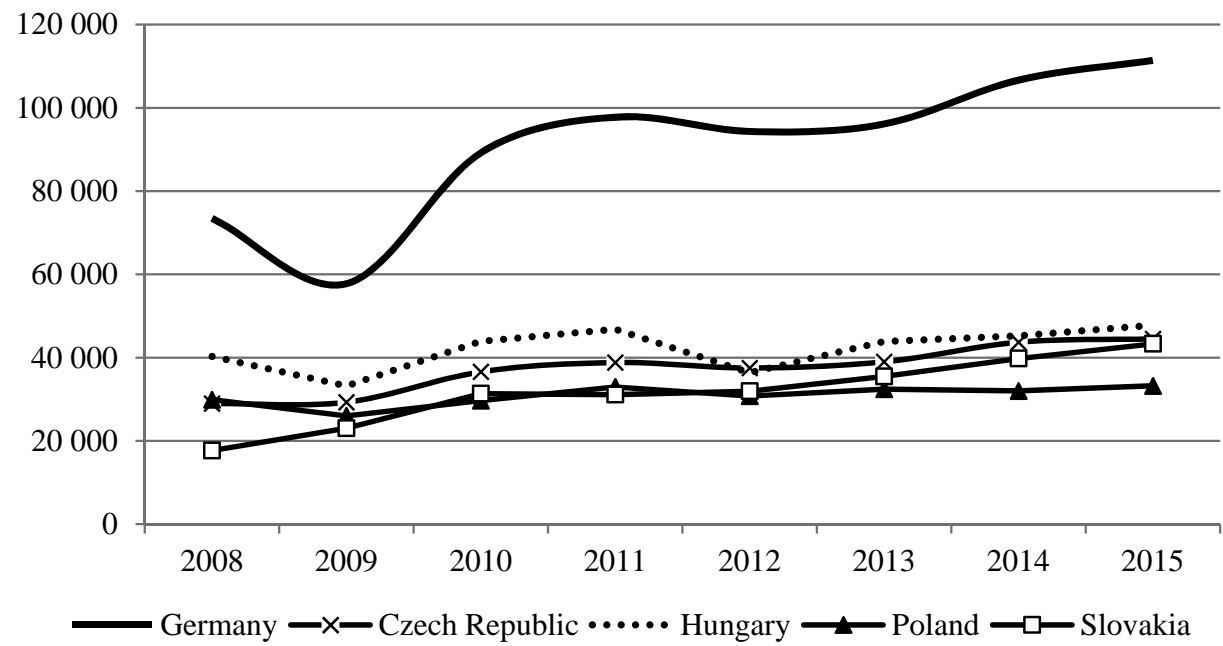

Figure 4. Labor productivity (Gross Value Added/employment) in the automotive industry in Germany and CEE (in euros)

Source: Eurostat.

content in a country's total volume of exports indicates that it is a 'downstream' participant in the supply chain, usually specializing in processing and assembly functions.

Although the modes of vertical specialization in CEE differ somewhat, the overall tendency toward a stagnant environment - one which produces little growth in value added - applies to all the countries under investigation here. We argue that there is no clear link between the growth of the industry's share in CEE economies and improvements in their capacity to produce value added. In fact, an inverse relationship applies when domestic value added by local production diminishes and can then be compensated for only by larger volumes of output. ${ }^{8} \mathrm{Be}$ tween 1995 and 2011, the share of domestic value added in gross exports dropped by 15 to 20 percent in each of the CEE countries despite their tendency to show increases in nominal export volumes. The region's increases in foreign value added are related to the growth of German value added in both nominal and relative terms (IMF 2013: 11). As noted by Cieślik (2014) CEE countries' growing share

8 The gross value added share in the automotive industrial output is extremely low in the CEE countries because of the strong import demand in the production. One notable example is Hungary where the production of one additional unit of gross value added in the automotive industry generates 3.22 additional units in the country's total imports (Kazimir et al. 2016: 10). 
of foreign value added in their total exports indicates a deteriorating position in the global value chain, i.e., with respect to downstream market segments.

More thorough statistics highlight the fact that such specialization does not always result in complementarities; the overall trend suggests an incoherently integrated intra-regional division of labor. Export statistics on product portfolios differentiate between two forms of specialization: supplying intermediate goods and assembling final goods (Molnár 2012; Kopint 2011). Incoherence arises as a result of parallel and competing activities that depend on commands from Western headquarters. Vertical specializations involve activities in which the West exports intermediate goods to be processed in downstream facilities in CEE, then re-exported directly or indirectly to the rest of the world (IMF 2013: 12). In Slovakia, for example, semi-final assembly dominates export activity, whereas in the Czech Republic there is a more balanced combination of final-product assembly and the supplying of parts. Interestingly, the supply of important intermediate goods for further processing elsewhere seems to dominate the Hungarian and Polish export portfolios (Ambroziak 2016: 36).

Because the process of standardization induces relocation, one of the most important export products of CEE automotive industries is the combustion engine (diesel and gasoline). The VW group, the biggest automotive investor in all the CEE countries, had already relocated much of the production of these engines to CEE even before the diesel scandal began to haunt it, which suggests that the combustion engine has been in the final phase of its life cycle for some time. The restructuring of the production process induced by this scandal and the consequent relocation of various models provide further evidence of this type of vertical specialization. According to Krzywdzinski (2008), the direct relocation of production has not resulted in an East-West division of labor, but rather in the renegotiation of product allocation to various European sites, which usually takes place with each new generation of products. In 2016, Audi (part of the VW group) decided to outfit its Brussels plant for the production of electric cars and transfer its older A1 models from Belgium to the Martorell plant in Spain. Audi's Q3 model, formerly produced at the Spanish factory, was then transferred to Györ, Hungary as a part of the process of model upgrades described above. General Motors' Opel division, the only other manufacturer of engines in Hungary, also recently upgraded its motor fabrication plant in Szentgotthárd (see Figure 5). In 2015, Audi's plant in Györ was the single biggest engine factory in the world.

Similar restructuring has occurred in Daimler's Mercedes division. The core factory in Bremen has been dedicated to the future production of electric cars, whereas the production of older models of compact (B-class) and sub-compact cars is being relocated to its newly built engine plant in Jawor, Poland and its expanded body plant in Kecskemét, Hungary. 


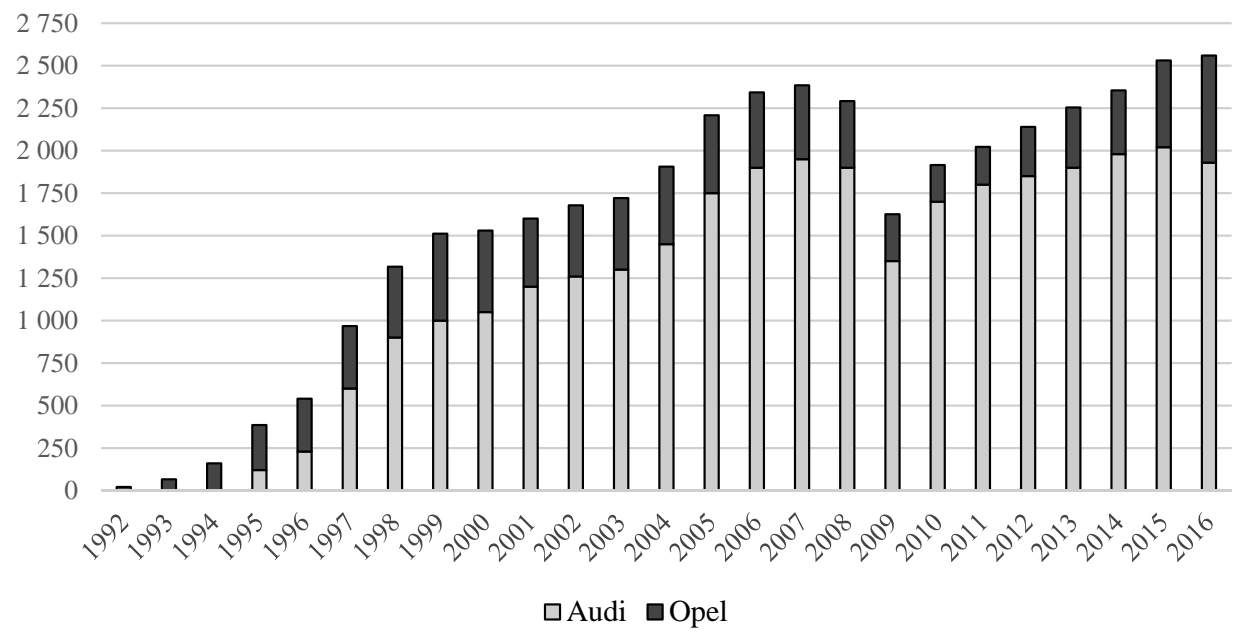

Figure 5. Engine production in Hungary, 1992-2016 (per 1000 unit)

Source: authors, based on company reports.

The reorganizational pressure stems from the changing network relations inside the value chain which can ultimately lead to changes in the governance structure (Kaplinsky 2005). Conflicts usually arise when lead firms attempt to protect their core competencies while major suppliers attempt to upgrade their position in the value chain. This is exactly what is happening in the automotive industry due to the above described technological transformation. One reason is that traditional OEMs lagged substantially behind major assembler in developing electric batteries which constitute a separate technological part of the engine. The major suppliers of these batteries are giant South Korean and Japanese corporations, including Panasonic, LG Chem, Samsung and the Chinese BYD which is uniquely a brand manager with its own developed batteries. Chinese manufacturers will be in a position to bring competitive electric automobiles to the market to a growing extent partly due to the state support. In reaction, OEMs such as BMW and VW, including Audi launched initiatives to catch up and develop their own battery production in fear of losing competitive advantage and market position over those independent suppliers who could achieve dominance in the value chain if the need for electric batteries will rise. Nonetheless, network relations among firms impact countries in which they reside (Humphrey 2000). CEE production will presumably be specialized even more in standardized manufacturing concerning e.g. batteries for European car production. It is, however, a matter of further research to what extent the origin of the producer - whether European or non-European - makes a difference for dependency (cf. Bartlett - Seleny 1998). 


\subsection{Modes of labor organization and value capture}

Both the various forms of labor organization and the different positions local companies take in global value chains are determined by core-periphery relationship. One notable result of relocation is that wages tend to lag behind labor productivity (Krzywdzinski 2008: 14; Cieślik 2014; Drahokoupil - Piasna 2018; see Figure 6). The source of exploitative rent is thus the constant gap between wages and productivity in the European automotive value chain. Profit consolidation presupposes this gap and results in sharply contrasting modes of labor organization in the West and in CEE. Despite higher unit labor costs, the high-road model in Western Europe benefits from cutting-edge technological innovations that help it to sustain high levels of productivity (Jürgens - Meissner 2005: 15). In addition, the protection of this model includes concessions in which lower-paying, lower-quality work is relocated to lower-wage countries.

As Krzywdzinski has demonstrated with regard to the supplier segment, labor-intensive mass production with relatively low skill requirements has almost completely disappeared from Germany; the standardized production of spare parts and components has also been affected by relocation. The recent drop in the number of blue-collar workers has contributed to a re-structuring of the whole

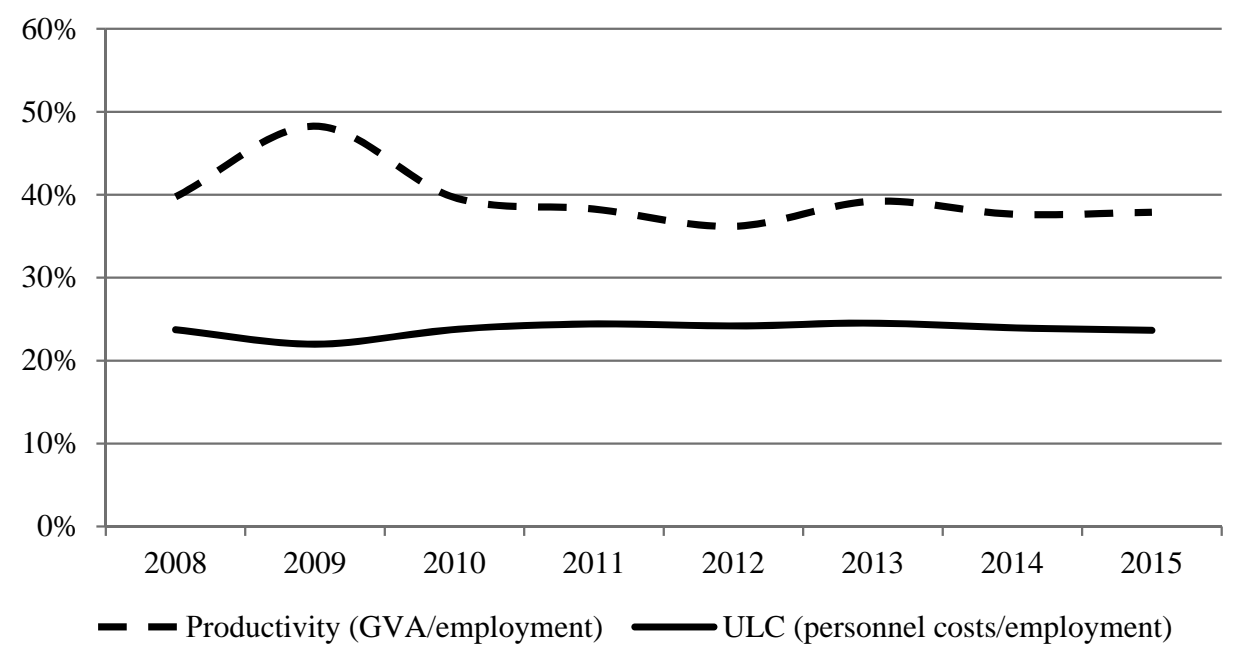

Figure 6. Gap between productivity and unit labor costs in the automotive industry in CEE countries (average) compared to Germany (100\%)

Source: Eurostat. 
German workforce. ${ }^{9}$ Losses caused by relocation have been counterbalanced by successful specialization in premium, high-tech, and high-quality products (Krzywdzinski 2014: 15).

Labor-market conditions for semi-skilled labor in CEE are already marked by intense competition and insecurity. The labor market consists of flexible fixedterm contractors, a largely non-unionized labor force, and temporary agency workers ${ }^{10}$ who can be easily integrated into production lines during reorganizations and model upgrades and whose employment is thus the most sensitive to the business cycles (Tardos - Piroska 2015; Meszmann 2016; Geröcs et al. 2018; Drahokoupil -Piasna 2018). Job security is generally limited to a thin stratum of the workforce.

The core-periphery relationship in the vertical specialization also circumscribes a firm's position in the automotive value chain, i.e. its ability to capture value. According to Henderson et al. (2002: 449), 'it is one thing for value to be created and enhanced in given locations, but it may be quite another for it to be captured for the benefit of those locations'. The possibility of value capture in a local context is determined by property relations and the value chain's governance structure.

Assessing property relations involves analyzing the number and strength of TNCs vis-à-vis domestic firms both inside the value chain and in a local economy. The property structures of the CEE automotive industry are characterized by a surprisingly high level of concentration, which has tended to grow over time (Kopint-Tárki 2008). Foreign corporations with a global presence dominate the value-chain hierarchy from the top level-lead firms or OEMs - down to the mid-bottom of tier-2. ${ }^{11}$ Companies with significant domestic ownership of operations above tier- 2 are very rare in the CEE countries. In fact, the share of domestic suppliers is decreasing even among tier-3 firms in some of the countries under consideration. In Hungary, for instance, the Hungarian Central Statistical Office's database shows that the number of domestic companies in the automotive industry decreased from 98 to 63 between 1998 and 2015. Similar trends are at work in the Czech Republic and Slovakia. As Pavlínek (2015) has shown, this declining share of domestic suppliers in the value chain has had a significant impact on overall economic development. TNCs in the Czech and Slovakian automotive in-

9 Low-skill production with no educational requirements - e.g., the assembly of wire-harness systems and the simple, high-volume production of automobile seats - was the first to be removed from Germany to low-wage countries (Krzywdzinski 2014).

10 Volkswagen's share of temporary agency workers, for instance, is about $10-20 \%$ of its EE workforce, compared to an average of 2\% at its German sites (Krzywdzinski 2008: 13).

11 In Hungary, for instance, around $90 \%$ of the assets in the industry are foreign owned (KopintTárki 2008: 48). 
dustries have reacted differently to the economic downturn, responding with different employment policies and making much greater use of profit repatriation.

The governance structure of the European automotive value chain reflects the hierarchies inherent in vertical specialization. The profitability crisis in the automotive industry has forced lead firms at the top of the value chain to delegate tasks and competencies that have been devalued as a result of standardization, and thus the possibility of capturing value has changed accordingly. Companies at lower levels in the chain face growing costs because new competencies have been delegated to them. Companies that are unable to perform these new tasks lose their positions in the chain and are forced either to leave the market or to reposition themselves at lower levels. Profits are thus distributed unevenly over the length of the value chain.

Tier-3 firms have suffered most from the profitability crisis. On the one hand, tier-3 companies tend to improve their capabilities by developing financial and technological dependencies on their higher-level partners (Pavlínek - Janák 2007). On the other hand, growing costs and intensifying competition have made value capture more and more difficult; the resulting pressure has forced many tier-3 companies to exit the market, which has contributed to the growing concentration of foreign ownership in local property structures. The governance structure at the lower levels of the value chain has become captive and hierarchical, with rigid dependencies and growing price competition. The effects of this pressure, such as low profitability and difficulties in capturing value, have not been distributed evenly, even among tier-3 companies. In the captive structure, foreign TNCs and their domestic suppliers are affected differently. Despite growing pressure, TNCs can still generate exploitative rents. Domestic suppliers, who are typically trapped at tier-3, have limited access to technological innovations and financial resources, and therefore remain financially more dependent on their higher-level partners to cover the costs of the technological and labor investments they will need to make in order to master new competencies, carry out new tasks, and capture value (Kopint-Tárki 2008: 49). When competition intensifies, they face a greater risk of bankruptcy.

As our empirical findings on the unevenness of capital intensity and labor productivity and value capture in value-chain specialization have demonstrated, core-periphery relations are not undone by the expansion of automotive value chains. On the contrary, vertical specialization in value chains is induced by similar global economic forces, such as technological transformation, that have historically been responsible for uneven development and uneven exchanges between core and peripheral countries. The difference now is that these hierarchical structures are more embedded in global production networks which also produce new geographical scope for interstate relations. This does not mean, however, 
that core-periphery is no longer relevant in the East and West relationship. In fact, companies on the top of the value chain hierarchy have remained geographically concentrated in Western Europe, most notably in Germany, whereas those who specialized in standardized activities have transferred production to Eastern Europe. As a conclusion, we find it accurate to apply the dependency theory not only in the interstate relations but also with respect to vertical specialization in value chains. Even though these two levels of the international division of labor are neither the same - as the logic of specialization, e.g. technological or labor processes affect states and interfirm connections in a different way - nor neutral to each other, but overlap to the extent that core-periphery relations have been reproduced by them.

\section{CONCLUSIONS}

We have argued in this paper that vertical specialization in the automotive value chains was one of the dominant forms in which core-periphery relationships reappeared between CEE and Western Europe, most notably Germany. One major force behind such specialization has been an unfolding technological transformation in the production of automotive engines since the economic crisis in 2008. The standardization of electric engines and batteries, along with the subsequent over-maturity of the combustion engine - the production of which CEE countries have specialized in - has provided a framework for the core-periphery relationship apparent in these production processes. This vertical specialization has had notable consequences for (1) labor productivity and capital intensity, and (2) modes of labor organization and capturing value. Although we have emphasized the core-periphery relationship that governs patterns of vertical specialization in automotive value chains (which we regard as a crucial aspect of dependen$\mathrm{cy}$ ), we believe that an understanding of the complex nature of the core-periphery relationship will require the elaboration of several other aspects of the global economy. These include investigations of external finances (Gerőcs - Pinkasz 2018), labor conditions in semi-peripheral positions in the international division of labor, and in the local context, class relations and the role of the state. 


\section{REFERENCES}

Ambroziak, Ł. (2016): FDI and Intra-Industry Trade in the Automotive Industry in the New EU Member States. International Journal of Management and Economics 52(1): 23-42.

Arrighi, G. (1990): The Developmentalist Illusion: A Reconceptualization of the Semiperiphery. In: Martin, W. G. (ed.): Semiperipheral States in the World-Economy. Westport, CT: Greenwood Press, pp. 11-42.

Bair, J. (2005): Global Capitalism and Commodity Chains: Looking Back, Going Forward. Competition \& Change 9(2): 153-180.

Baldwin, R. - Ito, T. - Sato, H. (2014): The Smile Curve: Evolving Sources of Value Added in Manufacturing. Joint Research Program Series, IDE-JETRO.

Bartlett, S. - Seleny, A. (1998): The Political Enforcement of Liberalism: Bargaining, Institutions, and Auto Multinationals in Hungary. International Studies Quarterly 42(2): 319-338

Becker, J. (2016): Europe's Other Periphery. New Left Review (II/99): 39-64.

Bernaciak, M. (2011): Trade Union Responses to Cross-Border Competition in the Enlarged EU: Evidence from the Automotive and the Construction Sectors. PhD thesis, Central European University.

Bohle, D. - Greskovits, B. (2012): Capitalist Diversity on Europe's Periphery. Ithaca, NY: Cornell University Press.

Boyer, R. - Freyssenet, M. (2002): The Productive Models: The Conditions of Profitability. London: Palgrave.

Brenner, R. (2006): The Economics of Global Turbulence: The Advanced Capitalist Economies from Long Boom to Long Downturn, 1945-2005. London: Verso.

Cardoso, F. H. (1972): Dependency and Development in Latin America. New Left Review (I/74): $83-95$.

Chase-Dunn, C. (1998): Global Formation: Structures of the World-Economy, Updated Edition. Lanham, MD: Rowman \& Littlefield.

Cieślik, E. (2014): Post-Communist European Countries in Global Value Chains. Ekonomika 93(3): 24-38.

Drahokoupil, J. - Piasna, A. (2018): Dependent Market Economies and Wage Competition in Central and Eastern Europe. In: Gerőcs, T. - Szanyi, T. (eds): Market-Liberalism and Economic Patriotism in Capitalist Systems: The Role of State in Varieties of Capitalism. London: Palgrave.

Fröbel, F. - Heinrichs, J. - Kreye, O. (1981): Krisen in der kapitalistischen Weltökonomie. Reinbek: Rowohlt Verlag.

Gereffi, G. (2014): Global Value Chains in a Post-Washington Consensus World. Review of International Political Economy 21(1): 9-37.

Gereffi, G. - Evans, P. (1981): Transnational Corporations, Dependent Development, and State Policy in the Semiperiphery: A Comparison of Brazil and Mexico. Latin American Research Review 16(3): 31-64.

Gereffi, G. - Humphrey, J. - Sturgeon, T. J. (2005): The Governance of Global Value Chains. Review of International Political Economy 12(1): 78-104.

Gereffi, G. - Korzeniewicz, M. (eds) (1994): Commodity Chains and Global Capitalism. Westport, CT: Praeger.

Gerőcs, T. - Pinkasz, A. (2018): Debt-Ridden Development on Europe's Eastern Periphery. In: Boatcă, M. - Komlosy, A. - Nolte, H.-H. (eds): Global Inequalities in World-Systems Perspective: Theoretical Debates and Methodological Innovations. New York, NY: Routledge, pp. 131-153. 
Gerőcs, T. - Meszmann, T. T. - Pinkasz, A. (2018): Uneven Development in Labour Relations: Fragmentation and Flexibilization in the Hungarian Automotive Industry. In: Komlosy, A. Musić, G. (eds): Global Commodity Chains and Labour Relations. Leiden: Brill.

Henderson, J. - Dicken, P. - Hess, M. - Coe, N. - Yeung, H. W.-C. (2002): Global Production Networks and the Analysis of Economic Development. Review of International Political Economy 9(3): 436-464.

Humphrey, J. (2000): Assembler-Supplier Relations in the Auto Industry: Globalisation and National Development. Competition \& Change 4(3): 245-271.

IMF (2013): German-Central European Supply Chain: Cluster Report. IMF Country Report 263.

Jürgens, U. - Meissner, H.-R. (2005): Arbeiten am Auto der Zukunft: Produktinnovationen und Perspektiven der Beschäftigten. Berlin: Edition Sigma.

Kaplinsky, R. (1998): Globalization, Industrialization and Sustainable Growth: The Pursuit of the Nth Rent. IDS Discussion Paper 365.

Kaplinsky, R. (2005): Globalization, Poverty and Inequality: Between a Rock and a Hard Place. Cambridge: Polity.

Kazimir, R. I. - Murai, B. - Anwar, K. - Száraz, A. - Salamon, A. (2016): Analysis of Productivity Trends in 'Manufacture of Motor Vehicles' Industry in Hungary. Presented at the International Association for Research in Income and Wealth General Conference, Dresden, Germany, August 25. http://www.iariw.org/dresden/kazimir.pdf, accessed 23/02/2018.

Kopint (2011): A magyar kis és középvállalatok beszállitói szerepének erősitéséről szóló stratégia kidolgozása a gép- és gépjármüipari ágazatban: A jelenlegi helyzet tanulságai és a lehetöségek kihasználásának eszközei [Policy for Strategic Adaptation for Enhancing the Role of Hungarian SME Suppliers in the Automotive Industry: Lessons from the Current Situation]. Budapest: Kopint.

Kopint-Tárki (2008): A jármüipari ágazati stratégia kialakitását megalapozó szakmai átvilágitó tanulmány [Strategy Monitoring for the Automotive Industry]. Budapest: TÁRKI.

KPMG (2015): KPMG's Global Automotive Executive Survey 2015: Who Is Fit and Ready to Harvest? https://home.kpmg.com/content/dam/kpmg/pdf/2015/04/global-automotive-executivesurvey-2015.pdf, accessed 23/02/2018.

Krzywdzinski, M. (2008): Work Models Under Strain of Offshoring East-West Competition in the European Car Industry. Paper for the $16^{\text {th }}$ GERPISA International Colloquium, Turin, 19 June.

Krzywdzinski, M. (2014): How the EU's Eastern Enlargement Changed the German Productive Model: The Case of the Automotive Industry. Revue de La Régulation 15(1): 1-20.

Meszmann, T. T. (2016). The Rise of the Dual Labour Market: Fighting Precarious Employment in the New Member States through Industrial Relations (Precarir). Country Report: Hungary. CELSI Research Report 12.

Molnár, E. (2012): Kelet-Közép-Európa az autóipari nemzetközi munkamegosztásban [Central and Eastern Europe in the international division of labour of automotive industry]. Tér és Társadalom 26(1): 123-137.

Nölke, A. (2016): Finanzialisierung als Herausforderung der Demokratie in Westlichen Industriegesellschaften. In: Brühlmeier, D. - Mastronardi, P. (eds): Demokratie in der Krise: Analysen, Prozesse und Perspektiven. Zürich: Chronos Verlag, pp. 107-118.

Pavlínek, P. - Janák, L. (2007): Regional Restructuring of the Škoda Auto Supplier Network in the Czech Republic. European Urban and Regional Studies 14(2): 133-155.

Portfolio (2016): Decembertől átmenetileg kevesebb autót gyárt a győri Audi [Audi in Győr to manufacture fewer cars after December]. https://www.portfolio.hu/users/elofizetes_info. php? $\mathrm{t}=\mathrm{cikk} \& \mathrm{i}=235412$, accessed 20/02/2019. 
Roberts, M. (2016): The Long Depression: Marxism and the Global Crisis of Capitalism Chicago, IL: Haymarket Books.

Šćepanović, V. (2013): FDI as a Solution to the Challenges of Late Development: Catch-up without Convergence? PhD thesis, Central European University.

Shanan, Z. (2016): Tesla's Battery Prices Falling Faster than Everyone Else's - Who Knew? CleanTechnica, June 8. https://cleantechnica.com/2016/06/08/teslas-batteries-cheaper-everyoneelses-knew-cool-ev-battery-charts/, accessed 23/02/2018.

Smith, A. (2015): The State, Institutional Frameworks and the Dynamics of Capital in Global Production Networks. Progress in Human Geography 39(3): 290-315.

Sturgeon, T. J. - Biesebroeck, J. Van (2011): Global Value Chains in the Automotive Industry: an Enhanced Role for Developing Countries? International Journal of Technological Learning, Innovation and Development 43(123): 181-205.

Tardos, K. - Piroska, D. (2015): Industrial Relations in the Context of Subcontracting: The Case of Hungary. In: López, M. M. - Diaz, M. A. (eds): Las Relaciones Laborales en el Contexto del Desarrollo de la Subcontratación / Industrial Relations in the Context of Development of the Outsourcing. Valencia: Tirant lo Blanch, pp. 237-252.

Vernon, R. (1966): International Investment and International Trade in the Product Cycle. The Quarterly Journal of Economics 80(2): 190-207.

Vliegenthart, A. (2010): Bringing Dependency Back In: The Economic Crisis in Post-Socialist Europe and the Continued Relevance of Dependent Development. Historical Social Research / Historische Sozialforschung 35(2132): 242-265.

Wallerstein, I. (1976): The Modern World-System: Capitalist Agriculture and the Origins of the European World-Economy in the Sixteenth Century. New York, NY: Academic Press.

Weissenbacher, R. (2018): Peripheral Integration and Disintegration in Europe: The "European Dependency School” Revisited. Journal of Contemporary European Studies 26(1): 81-98.

Open Access. This is an open-access article distributed under the terms of the Creative Commons Attribution 4.0 International License (https://creativecommons.org/licenses/ by/4.0), which permits unrestricted use, distribution, and reproduction in any medium, provided the original author and source are credited, a link to the CC License is provided, and changes - if any - are indicated. (SID_1) 